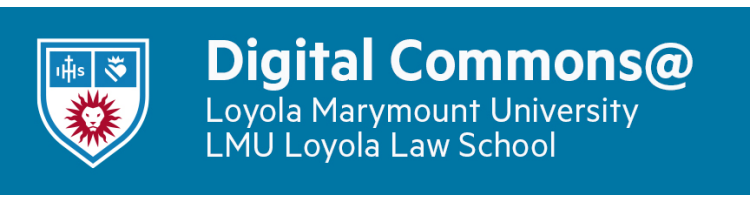

\title{
Journal of Catholic Education
}

$12-1-1999$

\section{Awakening Imagination Through Literature}

Rita E. Guare

Follow this and additional works at: https://digitalcommons.Imu.edu/ce

\section{Recommended Citation}

Guare, R. E. (1999). Awakening Imagination Through Literature. Journal of Catholic Education, 3 (2). http://dx.doi.org/10.15365/joce.0302072013

This Focus Section Article is brought to you for free with open access by the School of Education at Digital Commons at Loyola Marymount University and Loyola Law School. It has been accepted for publication in Journal of Catholic Education by the journal's editorial board and has been published on the web by an authorized administrator of Digital Commons at Loyola Marymount University and Loyola Law School. For more information about Digital Commons, please contact digitalcommons@lmu.edu. To contact the editorial board of Journal of Catholic Education, please email JCE@nd.edu. 


\title{
AWAKENING IMAGINATION THROUGH LITERATURE
}

\author{
RITA E. GUARE \\ Fordham University
}

Great literature can inspire reflection and give birth to transforming grace. Words matter; and because they do, literature often reveals the human condition and suggests avenues for growth and change. This article explores the power of literature to cause a spiritual awakening in school leaders. Several works are discussed as the author leads readers into deeply poetic reflections on the possibility of healing and redemption through reading.

wakenings are never easy. They illuminate "the boundaries in which all
territory" (Heidegger, 1968, p. 13). The clearing allows us to see what
Virginia Woolf called the "cotton wool of daily life" (1976, p. 72$)$, and draws
us to habits of being more alive in the world. Then, in the company of the
poet, we can sing

Many arrivals make us live: the tree becoming

Green, a bird tipping the topmost bough,

A seed pushing itself beyond itself,

The mole making its way through darkest ground,

The worm, intrepid scholar of the soil-

Do these analogies perplex? A sky with clouds,

The motion of the moon, and waves at play,

A sea-wind pausing in a summer tree.

What does what it should do needs nothing more.

The body moves, though slowly, toward desire.

We come to something without knowing why. (Roethke, 1966, p. 235) 
Awakenings like these particular life-giving arrivals make demands on us. In the presence of the spirit swelling in all creation, we remember what God asks of each of us: "to act justly, to love tenderly, and to walk humbly with your God" (Micah 6:8).

In Letters to a Young Poet, Rilke (1993) urged his student-disciple to similar awakenings. Often he encouraged the young poet to pay particular attention to the whisperings of imagination, that deeply felt sense that longs to liberate the human legacy by taking us beyond boundaries that bind and diminish the spirit. In reaching toward paths not yet in place and promises not yet realized, the human imagination awakens new levels of consciousness. This consciousness summons what is incomplete in us and in the human community and inspires personal journeys and communal quests toward wholeness and holiness.

Rilke advised his disciple to embrace the entire journey as gift and grace, including life's difficulties. He loved his student well enough to tell him to hold to the difficult. In this way, all that the young one feared would be transformed into a big happiness: "How should we be able to forget those ancient myths that are at the beginning of all peoples, the myths about dragons that at the last moment turn into princesses...?" (1993, p. 69). By awakening the transformative power of imagination, Rilke hoped to arouse in his student a vision for living consciously and deliberately and a voice for announcing and witnessing that:

There's nothing so small but I love it and choose

To paint it gold-groundly and great

And hold it most precious and know not whose

Soul it may liberate... $(1977$, p. 3$)$

Such vision and voice are rooted in the opened ground of love, a love that asks nothing in return but just spreads out touching more than we might have imagined and connecting us in webs of human solidarity.

Catholic educators appreciate the essence of Rilke's message, one that is intent on releasing the power of imagination. Indeed, many religious leaders acknowledge the inescapable horizons of a religious education with its power to celebrate and witness the happiness of Beatitude living, the compassion of strangers and Samaritans, and the justice of prophetic calls to consciousness and conversion. For Catholic-school leaders committed to the Good News, these gospel values are central to our mission to educate religiously.

This essay points to the critical role of the imagination in awakening the first stirrings of empathy, compassion, and justice. The arts and literature illuminate what Flannery O'Connor called the mystery and manners in life, while at the same time they nurture and nourish imaginative vision. Searching for particular pathways that join aesthetic education, the reader is invited to look for clearings and spaces where Catholic educators may reflect on the imaginative possibilities available in the arts. 
We need to learn how to invite imagination and mystery back into education. We must learn how to cleanse our vision so that, in the twenty-first century, we are not merely educating technicians and pragmatic thinkers but are calling forth a new vocation: vocations based on the profound aspiration to help all beings not-know, bear witness, and heal. (Halifax, 1999, p. 181)

Each of us understands our life's work and chooses to act in the name of the other by "hovering in thought and imagination around the enigmatic complexities of the seen particular" (Nussbaum, 1986, p. 69). Art is especially attentive to the zones of the particular. According to philosopher Martha Nussbaum:

We reflect on an incident not by subsuming it under a general rule, not by assimilating its features to the terms of an elegant scientific procedure, but by burrowing down into the depths of the particular, finding images and connections that will permit us to see it more truly, describe it more richly. (1986, p. 69)

Often artists address the social evils of the world through some form of particularity, which they value as an interpretive resource for human suffering. The possibilities of the particular expressed through literature have power to awaken new levels of consciousness.

\section{THE PASSION OF PARTICULARITY}

to reject the blur of the "universal";

to distinguish one life from another;

to illuminate diversity;

to light up the least grain of being,

to show how it is completely individual, particularized from any other;

to tell, in all the marvel of its singularity, the separate holiness of the least

grain. (Ozick, 1983, p. 248)

The uniqueness and distinctive character of each living and nonliving thing constitutes its particularity. In every age, artists have tried to capture single acts of meaning through drama. Antigone lives forever in the hearts of those who remember her stand against Creon. Her generous handful of dust sprinkled over her dead brother's unburied body was an act of holy defiance in the name of justice. On canvas, artists have illuminated single moments of being and thoughtfulness. One thinks of Monet's haystack at high noon, Van Gogh's starry night, and O'Keefe's light iris. Each of these works attempts to open spaces where we can see singularity in all its sacredness. Other artists invite us beyond limits to regions of hope where transcendence is possible. Like incense rising, Martha Graham's dance of lamentation liberates life and 
declares freedom once and again. The poet Wallace Stevens echoes this affirmation of life and things as they are in all their particularity.

The greatest poverty is not to live

in a physical world...

And out of what one sees and hears and out

Of what one feels, who could have thought

to make

So many selves, so many sensuous worlds,

As if the air, the mid-day air, was swarming

with the metaphysical changes that occur,

Merely in living as and where we live. (Stevens, 1972, p. 262)

Merleau-Ponty reminds us how important it is that we as subjects know our situations in all their rich contours, the inner and outer landscapes that define our meanings and purposes. He encourages us to return "to the site, the soil of the sensible and opened world such as it is in our life..." (1964, p. 160). The arts offer us glimpses of what John Dewey called "the practical character of reality" $(1934$, p. 54$)$ at the same time as they illuminate what Paulo Freire (1970) urged in critiquing unjust social situations in their concrete particularity. Are there ways that we can open spaces in our schools for wondering about justice and witnessing to its presence in "the separate holiness of the least grain"? Such an effort is more about "the changing shape of the thinkable" (Gordon, 1991, p. 3) than it is about existing practices of teaching and learning. In their revelatory power, the arts can engage us in asking how might we re-create ourselves into "the surprise of what is not yet possible in the histories of the spaces in which we find ourselves" (Rajchman, 1991, p. 163). The arts point us toward pathways where new levels of consciousness allow us the grace to imagine worlds not yet in place.

\section{PATHWAYS TO THE PARTICULAR}

Among twenty snowy mountains,

The only moving thing

Was the eye of the blackbird. (Stevens, 1972, p. 20)

The creative route is from particularity to universality. Instinctively, artists know this. They hover in thought and imagination about "the only moving thing," and their singular focus hollows "the eye of the blackbird." Artists intensify attentiveness to the concrete world within which we live and move and have our being. Attending to things as they are, artists pursue paths that deeply honor local knowledge with all its character, color, and contours, while at the same time evoking a kind of sympathetic or tacit knowing which acknowledges meanings that lie just below the surface of all things. 
Literature lures us to examine the promise and the paradox that reside in particularities, to explore other perspectives and possibilities, and to imagine lovelier and more just ways of living in the world. On another level, literature can open us to feelings of immediacy, posture us for moves toward solidarity, and engage us in critiquing social situations that dehumanize. I remember Toni Morrison's Beloved (1987) awakening in me feelings of outrage about slavery, empathy for the lost and the exiled, and determination to question things as they are. In one moving scene, we learn how Baby Suggs felt having her children sold.

[He was] the last of her children, whom she barely glanced at when he was born because it wasn't worth the trouble to learn features you would never see change into adulthood any way. Seven times she had done that: held a little foot; examined the fat fingertips with her own-fingers she never saw become the male or female hands a mother would recognize anywhere. She didn't know to this day what their permanent teeth looked like; or how they held their heads when they wailed. Did Patty lose her lisp? What color did Famous' skin finally take? Was that a cleft in Johnny's chin or just a dimple that would disappear soon as his jawbone changed? Four girls, and the last time she saw them there was no hair under their arms. Does Ardelia still love the burned bottom of bread? All seven were gone or dead. (p. 139)

I remember reading the particularities of this passage over and over again, feeling the unspeakable sorrow of mothers and children torn from each other. I fell silent. It seemed like the human thing to do in the face of inexplicable suffering. My silence preceded a painful awakening, for it opened me to a profound awareness of a pervasive waste of life around us. My awakened consciousness was accompanied by rich imaginings of how life might be otherwise not only for Baby Suggs and her children but also for all those whose lives are stolen.

On another level, literature can clarify and sharpen reality, drawing our attention to what we might have violated, ignored, or simply missed. I am reminded of the unloved character, Pecola, in The Bluest Eye (Morrison, 1970). Pecola lives at the rim of the edge, in the borderland of lost and abused children. Ultimately, she is destroyed by a culture that refuses to see her, by a mother who could not love her, and by friends who betray her. "We tried to see her without looking at her, and never, never went near. Not because she was absurd or repulsive, or because we were frightened, but because we had failed her. Our flowers never grew" (1970, p. 159). The narrator experiences something of a conversion as she reflects on an entire land that seemed hostile to life, where certain seeds will never nurture, where victims stay victims and die. This novel deeply touched me as a teacher. It urged me to love more tenderly some of those students who, like Pecola, were invisible to my inner eye. 
The works of Morrison have the capacity to take us into new and unexpected worlds where pain and sorrow are transformed into life-giving lessons. The pathways opened by these and other literary works involve excursions of possibility for renewing and re-creating the face of the earth. Further, these pathways create space for reflecting on a pedagogy that honors the aesthetic and spiritual dimensions of life.

\section{A POSSIBLE PEDAGOGY}

The wonder and mystery of art, as indeed of religion in the last resort, is the revelation of something wholly "other" by which the inexpressible loneliness of thinking is broken and enriched (Stevens, 1957, p. 238).

Artists create unified images for us. They craft these images in such a way that others can see the nature of the thing itself and feel the honesty, originality, and exactness of the work. Their delight in creation or defiance about things as they are conveys a delicate trust, which enables them to particularize reality. Where others might observe the general landscape of the farm, William Carlos Williams sees:

a red wheel

barrow

glazed with rain

water

beside the white chickens (1968, p. 30).

Or recall Alice Walker's image of 14-year-old Celie trying to chase that old white man, God, out of her head so she could see a field of purple flowers.

Well, us talk and talk about God, but I'm still adrift. Trying to chase that old White man out of my head. I been so busy thinking about him I never truly notice nothing God make. Not a blade of corn (how it do that?) not the color purple (where it come from?) not the little wild flowers. Nothing. Now that my eyes opening, I feels like a fool. (1982, p. 179)

Or consider Arthur Miller's image of a desperate salesman salvaging whatever shreds of self-respect remain. We can almost see Willy Loman's broken spirit. Listen as he pleads for the only life he knows.

Willy: God knows, Howard, I never asked a favor of any man. But never asked a favor of any man. But I was with the firm when your father used to carry you in here in his arms.... 
Howard: I appreciate that Willy, but there just is no spot here for you.... Willy: Howard, all I need to set my table is fifty dollars a week... (after other pleadings and stories of the past)

Willy: If I had forty dollars a week-that's all I'd need. Forty dollars. Howard. (1949, pp. 80-81)

We cannot separate nor reconstruct these images. They remain powerful reminders of our experience with these literary works. Only in the experience of the poem, the novel, or the play can we recognize the importance of image with its capacity to shock us into new awareness, new consciousness.

To convey the meaning of something substantial you have to use not a shadow but a sign, not the imitation but the image. The image is a new and different reality, and of course it does not convey an impression of some object, but the mind of the subject: and that is something else again. (Merton, 1966, p. 134)

If we remain open to the particular literary work, to the experience of the thing itself, the images come alive. Obvious meanings point to deeper and more plural meanings, and these are inexhaustible.

I am deeply challenged by the keen sights of artists in particularizing things and in unifying elements in order to make one image, the vision. In leading Catholic schools, I wonder how we can learn to welcome "the wonder and mystery of art" (Stevens, 1957, p. 238) into our work as administrators and teachers. I believe such an effort will involve connecting "with the manner in which we conduct various activities. We discuss or think critically...we paint or cook creatively and integrity is shown in our moral life or in a work of art" (Peters, 1975, p. 121).

To concern ourselves "with the manner in which we conduct various activities" (Peters, 1975, p. 121) suggests the possibility of a new consciousness for our work in leading Catholic schools and a fresh vitality in its practice. That consciousness prizes certain qualities of mind and soul, and that vitality lives to see the critical and creative thinking of compassionate and caring spirits in action. As administrators and teachers, we cultivate these cherished values by embracing a kind of mindfulness that compels us "to think what we are doing" (Arendt, 1958, p. 5). Such thinking may lead us to conduct various activities and practices that transcend limits by stretching imaginative visions and transgress boundaries by resisting what diminishes the life of teaching and leaming.

Catholic school leaders intentionally cultivate an awareness of and encourage patterns of action for thoughtfulness, transgression, and transcendence. Imaginative literature is rich with texts for illuminating these modes of engagement, which I am encouraging leaders to develop in themselves and in the learning communities they lead. On another level, however, experience 
with works of imaginative literature has the power to prompt and provoke the continued fresh thinking our work desperately needs to keep our hearts from hardening and our spirits from despair.

What I am pressing for is the continual expansion of human capacities when leaders see and promote literature as enlarging a curriculum to include teaching and learning for thoughtfulness, for transgression, and toward transcendence. I have in mind three novels that reveal ways of being and acting in the world worthy of critical and creative reflection. Albert Camus' novel The Plague helps us to see things as they are and summons the only hope in times of pestilence: thoughtful action. Ralph Ellison's Invisible Man takes us beneath the city life of New York to find the rage and resignation of racism. In times like these, silence must be broken and the story must be told. Finally, in the last novel, The Song of the Lark by Willa Cather, we see the struggles of an artist and know the cost of the song that goes beyond her.

Each of these novels has the capacity to make one "see, finding encouragement, consolation, fear, charm-all you demand-and, perhaps, also that glimpse of truth for which you have forgotten to ask" (Conrad, 1967, pp. ix$\mathrm{x})$. It is not my attempt to explicate the rich meanings that each of these novels holds. I can only hope to draw on the images in these works to help us see the "revelation of something wholly 'other'" (Stevens, 1957, p. 238).

\section{THOUGHTFULNESS: SEEING WHAT IS}

In calling forth thoughtfulness from leaders in this age of standardization and reform and in encouraging them to mind this call in shepherding new consciousness, something new is happening. I am not talking about the kind of shallow thinking that Wallace Stevens characterizes as confined to "square hats" and "square rooms" (1964, p. 75). I am not talking about thinking as skill, concept-driven, or outcome-based. I am not discarding these; they have a valuable place within the frameworks of teaching and learning. Rather, what I want to invoke is a kind of thinking that has a moral and ethical dimension to it. I want to propose that there is virtue in being thoughtful.

The thoughtful person avoids both impulsive and stereotyped responses because he or she is wont to do so. Thoughtfulness becomes instinctive, but it is not blind or mechanical since it derives from an appreciation of its own value.... Learning to be thoughtful is not learning to perform a particular action nor is it acquiring a method of obtaining a particular result; it is developing a "second nature" which transforms heart and mind. (Schrag, 1988, p. 80)

We see that second nature developing in Dr. Rieux, a leading character in Camus' novel The Plague. In the beginning of the story, when the pestilence hits the little French town, the people are cast about, hopeless and resigned 
to the incurable and inevitable death-dealing disease. At first, Dr. Rieux fights the disease dispassionately simply because that is what his job requires. Only later, when he sees in the face of his patients the horror of the plague's devastation, does he discover something deeper about his work. Instinctively, he knows he must rethink the manner of his work, revise the meaning and purpose of his practice. With renewed commitment, Dr. Rieux decides to fight vigilantly against the plague rather than conspire in its merciless mission against life. In his thoughtful effort to reclaim healing, we hear him speak of those "unable to be saints but refusing to bow down to pestilences," those who "strive their utmost to be healers" (Camus, 1948, p. 278).

I am reminded of certain administrators and teachers who do their jobs, dutifully but dispassionately, the way Dr. Rieux first approached his work. After all, what more can one do when crisis threatens the very enterprise to which we have committed ourselves? Tarrou helped Dr. Rieux see how together they could empower a people grown weary and hopeless to fight against the power of the plague. Thus, Dr. Rieux came to understand his work in a deeper way. In rereading this novel, I wonder what are the "pestilences" in our schools today to which some of us will refuse to bow. I wonder what it will cost us "to strive" our "utmost to be" educators and to teach as Jesus did.

\section{TRANSGRESSION: SEEING BENEATH THE SURFACE}

The idea of transgression is rooted in learning communities, in the struggle for the meaning in human history, not in some romanticized notion of protest. That theme is powerfully taken up in Ellison's novel Invisible Man. The nameless protagonist says that his invisibility "occurs because of a peculiar disposition of the eyes of those with whom I come in contact. A matter of the construction in their inner eyes, those eyes with which they look through their physical eyes upon reality" (Ellison, 1952, p. 7). In a cellar in New York City, he recounts all that has happened to him; it is his story of hope and disillusionment. His experience as a Black man whose deeds and dreams are destroyed is the story that he tells. What he learns is that telling his story is vital. Through it a pattern of transgression emerges from the chaos of a shattered life.

What the protagonist crafts is a story within the story, and, in the process, he creates a new life with new purpose. Echroed in the last line of the novel is a deeper level of consciousness and a new understanding of his work for justice when he says "Who knows but that, on the lower frequencies, I speak for you?" (Ellison, 1972, p. 439). Like Tarrou in The Plague who "resolved always to speak-and to act-quite clearly" and who "decided to take in every predicament, the victims' side so as to reduce the damage done" (Camus, 1948, p. 230), the nameless narrator, by the end of his story, rises to those inescapable horizons of spirit. 
It is humbling to remember that as leaders who are shepherding Catholic education into the Jubilee Year of promise, we face the challenge of continual conversion, the reconstruction of our "inner eyes" by which we understand reality and question our visions and practices. We need to know what to resist and what to embrace especially from those who advertise the best practices and sure solutions to complex issues. We may need to ask ourselves every once in a while: "on the lower frequencies" for whom do I speak?

\section{TRANSCENDENCE: SEEING BEYOND THE BOUNDARIES}

In suggesting that Catholic-school educators recognize capacities for transcendence, I am not speaking here about those mystical and extraordinary moments that some people may experience. Rather, I am encouraging two kinds of pursuits. One pursuit involves an inner journey where we find within ourselves and within our learning communities those unfamiliar landmarks that reveal so much more about who we are. The other pursuit involves setting out in the company of others to uncover the common ground between us. Both pursuits are important in defining who we are and the "more" we are called to be.

The Song of the Lark by Cather (1915) illuminates with lasting appeal this theme of stretching beyond boundaries. The story is one of personal struggle as Thea Kronborg fights her way through exacting engagements and dull details in order to give herself more freely to the music she loves. In essence, the story is about a young girl's awakening to something beautiful and her escape from a world too narrow in order to know and live that beauty through song.

To know Thea's story is to remember the image of her "when she was at her best and became a part of what she was doing and ceased to exist in any other sense" (Cather, 1915, p. 176). It is to remember those "other times when she was so shattered by ideas that she could do nothing worth while; when they trampled over her like an army and she felt as if she were bleeding to death under them" (p. 176). Later, she would discover that "as she went over her work in her mind, the passages seemed to become something of themselves, to take a sort of pattern in the darkness" (pp. 176-177). Her art was being defined at the same time that she was being stretched beyond the boundaries of the musical arrangements she played.

Administrators know full well the experience of working long hours, practicing to be at one's best, and becoming so much a part of what one is doing that one almost disappears. There is joy in this; however, that experience often followed one where one felt "trampled over" by ideas, messages, memos. And, sometimes it was only later that some bigger purpose took on "a sort of pattern in the darkness." 
These books are personal stories. As such, they need to be read not as we read curriculum guides or teachers' editions of textbooks. We need to read these as human stories; "aesthetically-living the experience" (Newman, 1991 , p. xiv). We need to read aesthetically, pausing to reflect on the human condition of pain, suffering, joy, and triumph. We need to make connections with our own life, imagine a different set of circumstances so that we are prepared to speak and to act in the name of the other.

The issue is whether we will read literature only for those precious values and visions that we hold sacred or whether we can surrender and submit to an inner movement to see what insight, including a spiritual awakening, may have been revealed by our engagement with the work itself. A pedagogy that pursues thoughtfulness, transgression, and transcendence welcomes this surrender as power. Such a pedagogy issues invitations that we must respond to with our students, awakenings that we must encourage to happen, and clearings that we must keep open toward those inescapable horizons.

\section{EPILOGUE}

These are but a handful of ideas awakened and played out in light of the images that artists have created. Imaginative literature helps us as Catholic educators to consider:

-What is it like to be awake?

-What does it mean to think and to act thoughtfully?

- How can we move beyond boundaries that limit us and the learning communities that we lead?

- Do we remember what it feels like to transcend our visions, our hopes, and our very selves? Do we dare?

Rilke would invite us to have patience with questions and questing hearts. He would urge us to love the questions and live into the answers. I raise the question because I believe "It is important that everything we love be summed up into something unforgettably beautiful..." (Leiris, 1988, p. 210). So much depends on this awakening.

We wake and find ourselves on a stair; there are stairs below us which we seem to have ascended, there are stairs above us which go out of sight.... (Emerson, 1929, p. 252) 


\section{REFERENCES}

Arendt, H. (1958). The human condition. Chicago: University of Chicago Press.

Burchell, G., Gordon, C., \& Miller, P. (Eds.). (1991). The Foucault effect: Studies in governmentality: Chicago: University of Chicago Press.

Camus, A. (1948). The plague. New York: Alfred A. Knopf.

Cather, W. (1915). The song of the lark. Boston: Houghton Mifflin Company.

Conrad, J. (1967). Great short works of Joseph Conrad. New York: Harper Collins.

Dewey, J. (1934). Art as experience. New York: Minton. Balch \& Company.

Ellison, R. (1952). Invisible man. New York: Signet Books.

Emerson, R. W. (1929). Complete writings. New York: W. H. Wise.

Freire, P. (1970). Pedagogy of the oppressed. New York: Herder \& Herder.

Gordon, C. (1991). Governmental rationality: An introduction. In G. Burchell, C. Gordon, \& P. Miller (Eds.), The Foucault effect: Studies in governmentality (pp. 1-51). Chicago: University of Chicago Press.

Halifax, J. (1999). Learning as initiation: Not-knowing, bearing witness, and healing. In S. Glazer (Ed.), The heart of learning: Spirituality in education (pp. 173-181). New York: Penguin Putnam, Inc.

Heidegger, M. (1968). What is called thinking? New York: Harper Collins.

Leiris, M. (1988). Faire-part. In E. C. Oppler (Ed.), Picasso's guernica (pp. 195-220). New York: Norton.

Merleau-Ponty, M. (1964). The primacy of perception. Evanston, IL: Northwestern University Press.

Merton, T. (1966). Conjectures of a guily bystander. New York: Doubleday and Company.

Miller, A. (1949). Death of a salesman. New York: Penguin.

Morrison, T. (1970). The bluest eye. New York: Bantam Books.

Morrison, T. (1987). Beloved. New York: Knopf.

Newman, J. M. (1991). Interwoven conversations: Learning and teaching through critical reflection. Portsmouth, NH: Heinemann.

Nussbaum, M. (1986). The fragility of goodness. New York: Cambridge University Press.

Ozick. C. (1983). Art and ardor. New York: Alfred A. Knopf.

Peters, R. S. (1975). Education and human development. In R. F. Dearden, P. H. Hirst, \& R. S. Peters (Eds.), Education and the development of reason (pp. 501-520). London: Routledge.

Rajchman, J. (1991). Philosophical events: Essciys of the 80's. New York: Columbia University Press.

Rilke. R. M. (1977). Possibility of bcing: A selection of poems. New York: New Direction.

Rilke, R. M. (1993). Letters to a young poet. New York: Norton.

Roethke. T. (1966). The collected poems of Theodore Roethke. Garden City, NY: Doubleday \& Co.

Schrag. F. (1988). Thinking in school and society. London: Routledge.

Stevens, W. (1957). Opus posthumous. New York: Alfred Knopf.

Stevens, W. (1964). Collected poems by Wallace Stevens. New York: Alfred Knopf.

Stevens, W. (1972). The palm at the end of the mind: Selected poems and a play. New York: Random House.

Walker, A. (1982). The color purple. New York: Washington Square Press.

Williams, W. C. (1968). Selected poems of William Carlos Willians. New York: New Directions.

Woolf, V. (1976). Moments of being: Unpublished autobiographical writings. Orlando, FL: Harcourt.

Rita E. Guare is assistant professor in the Department of Administration and Supervision in the Graduate School of Education at Fordhum University. Correspondence concerning this article should be addressed to Rita E. Guare, Ph.D., Fordham Universily: 113 W'est 601h St., New York, NY 10023. 
Copyright of Catholic Education: A Journal of Inquiry \& Practice is the property of Catholic Education: A Journal of Inquiry \& Practice and its content may not be copied or emailed to multiple sites or posted to a listserv without the copyright holder's express written permission. However, users may print, download, or email articles for individual use. 